УДК 37.091.12:316.77-043.5

DOI: $10.37026 / 2520-6427-2021-108-4-55-62$

\section{Ірина ДУБРОВІНА,}

кандидат педагогічних наук,

дочент кафедри педагогіки і психології вищої школи

Національного педагогічного університету

імені М. П. Драгоманова,

науковий співробітник Інституту книгознавства

Національної бібліотеки України

імені В. І. Вернадського,

м. Київ, Украӥна

ORCID: 0000-0002-6676-4789

e-mail:iradubrovina@ukr.net

Наталія МАКСИМЕНКО-ГЛАДИШКО, вихователь закладу дошкільної освіти №726, студентка магістратури

Національного педагогічного університету імені М. П. Драгоманова,

м. Київ, Украӥна

ORCID: 0000-0002-6173-0678

e-mail:maksimenko_nat@ukr.net

Ольга ЗІНЧЕНКО,

науковий співробітник

Центру імітаційного моделювання

Національного університету оборони України

імені Івана Черняховського,

м. Київ, Украӥна

ORCID: 0000-0002-0733-3372

e-mail: olhazinchenko9@gmail.com

\title{
ФОРМУВАННЯ КОМУНІКАТИВНОЇ ВЗАЕМОДЇ̈ У ПЕДАГОГІЧНОМУ КОЛЕКТИВІ: ТЕОРІЯ ТА ПРАКТИКА
}

Анотація. У статті розглядаються шляхи та методи формування комунікативної взаємодії у педагогічному колективі. Комунікативна взаємодія схарактеризована як інтегративне, динамічне, структурно-рівневе утворення, представлене сукупністю комунікативних знань, умінь і навичок, а також комунікативно-значущих якостей особистості, щуо забезпечують у своїй взаємодії продуктивну професійну комунікативну діяльність. Доведено, щз удосконалення комунікативної взаємодії у педагогічному колективі повинно здійснюватися за активної допомоги фахівия дорадчо-методичної сфери. Визначено необхідність иілеспрямованого формування ефективної комунікативної взаємодії у рамках роботи педагогічної студї «Антиконфлікт». Поняття взаємодії розглядається як спосіб взаємозв'язку, взаємовпливу та умова розвитку всіх соціальних систем. Оскільки індивідуальна дія в людському сочіумі виконується в умовах прямих або непрямих відносин з іншими людьми, взаємодія передбачає водночас із фізичним і комунікативний аспект.

Прочес освітньо-професійного удосконалення фахівців щзодо оновлення змісту освітньо-кваліфікаційних програм, фахової практики, змісту практичних та семінарських робіт, творчих завдань, проведення тренінгів із комунікації та організації проблемних педагогічних студій потребує трунтовного дослідження.

Ключові слова: взаємодія, комунікативна взаємодія, групова співпраия, педагогічний колектив, освітній nростір.

\author{
Iryna DUBROVINA, \\ Candidate of Pedagogical Sciences, \\ Associate Professor of Pedagogy and Psychology \\ of the Higher School Department, \\ National Pedagogical Dragomanov University, \\ Kyiv, Ukraine \\ ORCID: 0000-0002-6676-4789 \\ e-mail:iradubrovina@ukr.net
}

\author{
Natalia MAKSYMENKO-GLADYSHKO, \\ Preschool Teacher of Preschool Institution №726, \\ Master of Educational and Pedagogical Sciences, \\ Kyiv, Ukraine \\ ORCID: 0000-0002-6173-0678 \\ e-mail:maksimenko_nat@ukr.net
}


Olga ZINCHENKO,

Researcher of Center for Simulation Modeling

Ivan Chernyakhovsky National University

of Defense of Ukraine,

Kyiv, Ukraine

ORCID: 0000-0002-0733-3372

e-mail : olhazinchenko9@gmail.com

\section{FORMATION OF COMMUNICATIVE INTERACTION IN THE COLLECTIVE: THEORY AND PRACTICE}

\begin{abstract}
The article considers the ways and methods of forming communicative interaction in the teaching staff. It is shown that communicative interaction is an integrative, dynamic, structural-level formation, represented by a set of communicative knowledge, communicative skills and abilities, as well as communicatively significant personality qualities that provide productive professional communicative activity in their interaction. It is proved that the improvement of communicative interaction in the teaching staff should be carried out with the active assistance of a specialist in the advisory and methodological scope. The necessity of purposeful formation of effective communicative interaction within the work of the pedagogical studio "Anti-conflict» is determined.
\end{abstract}

The concept of interaction is considered as a way of interconnection, interaction and a condition for the development of all social systems. Since individual action in human society is performed in direct or indirect relationships with other people, the interaction contains with the physical, communicative aspect too.

The process of educational and professional improvement of specialists in updating the content of educational and qualification programs, professional practice, the content of practical and seminar works, creative assignments, conducting trainings on communication and organizing problem pedagogical research requires careful research. Consequently, the structure of pedagogical interaction in the context of subject-subject interaction is determined on the basis of the following stages of its implementation: the first stage of interaction - awareness of the problem and purpose; the second stage of interaction - the perception of the interaction partner; the third stage of interactionmaking decision; the fourth stage of interaction - acts of communicative activity and behavior

We state that effective interaction in pedagogical activity is the main condition for success and satisfaction with collective work. At the same time, the inability to establish contact with colleagues is the cause of many failures and disappointments in the teaching profession.

Key words: interaction, communicative interaction, group cooperation, teaching staff, educational space.

Постановка проблеми. Сучасне освітнє середовище закладу освіти спрямоване на досягнення позитивних освітніх результатів, які б відповідали вимогам суспільства та створювали умови для розкриття особистісно-професійного потенціалу активних учасників у постійній співпраці. Тому формування комунікативної взаємодії стає невід'ємною складовою професійного вдосконалення спеціалістів-освітян. Однією із важливих складових дорадчо-консультаційної діяльності є комунікативна взаємодія з різними категоріями осіб: педагогічними працівниками, громадськістю, студентами, батьками, що актуалізує необхідність постійного оновлення знань, розвитку відповідних комунікативних навичок та вмінь, набуття досвіду співпраці в освітньому просторі. Питання формування комунікативної взаємодії в педагогічному колективі потребує детального розгляду, адже сьогодні на зміну традиційному методисту приходить фахівець 3 педагогічного консультування, експерт з якості освіти, що організовує та керує комунікативною взаємодією у педагогічному колективі. У зв'язку з цим процес освітньо-професійного вдосконалення фахівців з оновлення змісту освітньо-кваліфікаційних програм, фахової практики, змісту практичних та семінарських робіт, творчих завдань, проведення тренінгів із комунікації та взаємодії у педагогічному колективі, організації проблемних педагогічних студій потребують детального розгляду.

Аналіз наукових досліджень і публікацій. У педагогічній науці проблемі розвитку комунікативної взаємодії присвячено ряд досліджень, зокрема О. Бодальова, Ю. Смельянова, Г. Ковальова та ін. Проблема формування навичок та вмінь комунікативної взаємодії як важливого чинника професіоналізму освітян знайшла відображення у наукових працях Г. Бороздіної, П. Веселова, В. Грехньова, О. Даниленко та ін. Шляхи формування комунікативних умінь фахівців педагогічної сфери висвітлено у роботах О. Боброва, О. Бодальова, С. Бондаренка, С. Єлканова, В. Кан-Калика, А. Мудрик, Н. Кузьміної, В. Семиченко, О. Усової, Т. Шепеленко та ін.

Мета статті - обгрунтувати особливості формування комунікативної взаємодії в педагогічному колективі у теоретичному аспекті для проєктування ефективної співпраці та взаєморозуміння між колегами-освітянами.

Виклад основного матеріалу дослідження. Комунікативна взаємодія є одним із найважливіших компонентів професійної культури, а вміння ії налагоджувати виступає однією із вагомих складових професіоналізму педагога. Необхідність формування комунікативної взаємодії обумовлена тим, що педагогічний колектив закладу освіти постійно включений у процес спілкування $з$ різними категоріями осіб: дітьми, батьками, педагогічними працівниками, адміністрацією та ін. Для уточнення змісту поняття «комунікативна взаємодія» необхідно звернутися до сутності та змісту його складників. Так, комунікація - це поняття, близьке до поняття спілкування; загалом iï можна визначити як зв'язок, 
у ході якого відбувається обмін інформацією (Вольнова, 2011, с. 36). Поняття взаємодії розглядається як спосіб взаємозв'язку, взаємовпливу та умова розвитку всіх соціальних систем (Основи соціальної психології, 2008, с. 64). Оскільки індивідуальна дія в людському соціумі виконується в умовах прямих або непрямих відносин 3 іншими людьми, взаємодія містить, разом із фізичним, і комунікативний аспект (Куликов, 2012, с. 4).

Для вивчення такого поняття як «комунікативна взаємодія» слід розглянути цю проблематику у працях різних авторів.

Так, А. Бичок стверджує, що комунікативна взаємодія є умовою ефективності професійної діяльності спеціаліста та метою його професійного самовдосконалення (2010, с. 12). В. Садова визначає комунікативну взаємодію педагога як динамічне особистісне утворення, що містить у собі мистецтво мовлення і слухання, об'єктивне сприймання і правильне розуміння учня, сприяє побудові гуманних стосунків і досягненню ефективної взаємодії на основі спільних інтересів (Педагогічна творчість, майстерність, професіоналізм у системі підготовки освітянських кадрів: здобутки, пошуки, перспективи, 2015, с. 42).

О. Гаврилюк доводить, що комунікативна взаємодія - це складне динамічне особистісне утворення, що відображає соціально зумовлений рівень розвитку особистості, їі готовність до комунікативної діяльності, систему поглядів і дій, які забезпечують задоволення потреб самореалізації (2007, с. 10).

Оскільки в системі соціальних відносин взаємодія є основним способом інтеграції та координації дій людей або їх груп у процесі здійснення спільної діяльності, то, у зв'язку із викладеним, комунікативна взаємодія у закладі освіти тлумачиться нами як суб' Єкт-суб' єктна діяльність учасників освітнього процесу, спрямована на інформаційний обмін та спілкування, вирішення групових робочих завдань, створення творчих проєктів, обмін передовим педагогічним досвідом, вирішення міжособистісних конфліктів у площині професійної співпраці для необхідності знайти спільну думку. Така наукова дефініція поняття «комунікативна взаємодія» визначає здатність розвивати особистісні комунікативні навички та вміння фахівців та адекватно сприймати поведінку суб'єктів спілкування у закладі освіти, налагоджувати продуктивні міжособистісні стосунки з ними, майстерно використовувати вербальні та невербальні засоби впливу фахово-комунікативної спрямованості, формувати сприятливий емоційний мікроклімат у колективі, працювати над виявленням прихованого конфлікту та ін. (Коновчук, 2012, с. 91).

Серед багатьох соціальних підсистем, які взаємно впливають одна на одну у закладі освіти, ми виділили для аналізу підсистему «педагог-педагог» як таку, що має необмежені й недостатньо вивчені можливості для взаємообміну на особистість. Характеристики цієї підсистеми розглядатимемо з точки зору їх значущості для особистісно-професійної співпраці в умовах закладу освіти, та вважаємо, що взаємодія відбувається за чітко визначеними етапами (див. рис. 1).

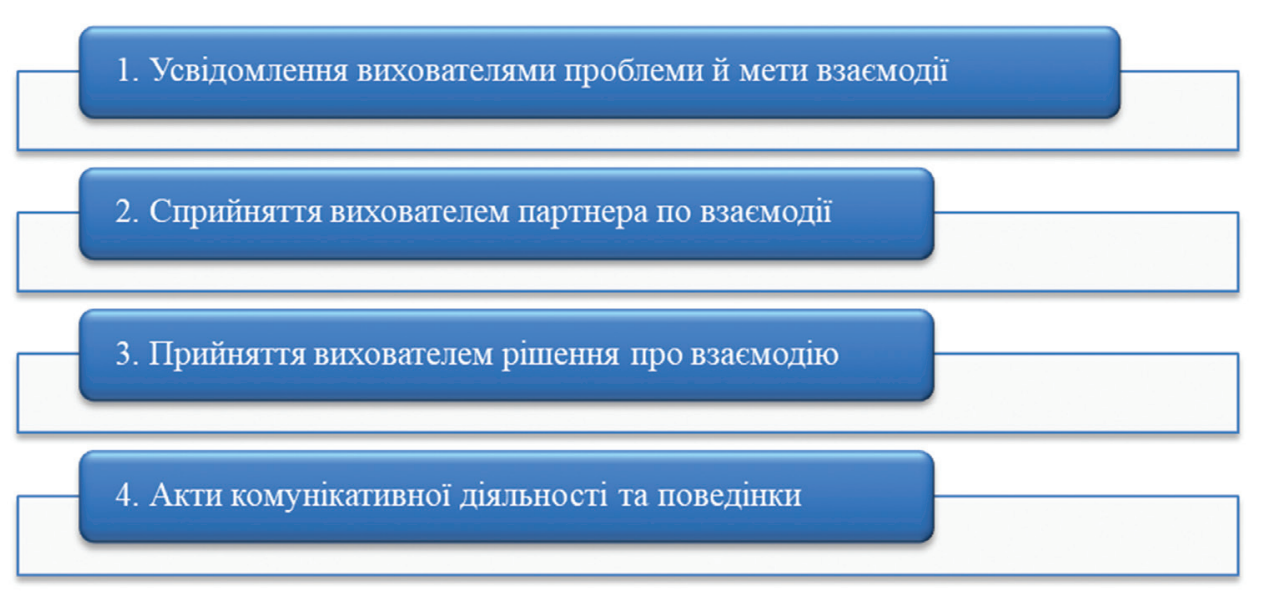

Рис. 1. Етапи педагогічної взаємодії у закладі освіти

Зважаючи на зазначене вище, структуру педагогічної взаємодії в контексті суб'єкт-суб'єктної взаємодії визначимо на основі таких етапів ії здійснення: перший етап взаємодії - усвідомлення проблеми й мети; другий сприйняття партнера взаємодії; третій - прийняття рішення; четвертий - акти комунікативної діяльності та поведінки. Констатуємо, що ефективна взаємодія в педагогічній діяльності є основною умовою успіху та задоволення колективною працею. Водночас невміння налагодити контакт із колегами - причина багатьох невдач і розчарувань у педагогічній професії.

До професійної діяльності педагога, за Л. Руденко, віднесемо такі функції: інформаційну (забезпечення педагогічних працівників закладу освіти норматив- ною та інструктивною документацією, методичною літературою), організаційну (організація різноманітних методичних заходів - педагогічних читань, науково-методичних конференцій і семінарів, виставок, конкурсів, створення банків передового педагогічного досвіду) й аналітико-консультаційну (аналіз та діагностика методичної діяльності педагогічних працівників, результатів моніторингу навчання, інформаційних запитів педагогів і керівників, проведення індивідуальних й колективних консультацій, виявлення методичних проблем закладу освіти) $(2015$, с. 112). Вказані завдання визначають функції педагогічної взаємодії у закладі освіти. Оскільки будь-яка взаємодія людей починається з розподілу функцій, то функції взаємодії 
грунтуються на взаємному врахуванні можливостей, які сприяють взаємодії та взаємній згоді й домовленості щодо керівництва взаємодією (Максименко, 2005, с. 82). Керівництво, з одного боку, обмежує свободу дій кожного, але з іншого - дає можливість виявити себе в загальній справі (Яновська, 2017, с. 95).
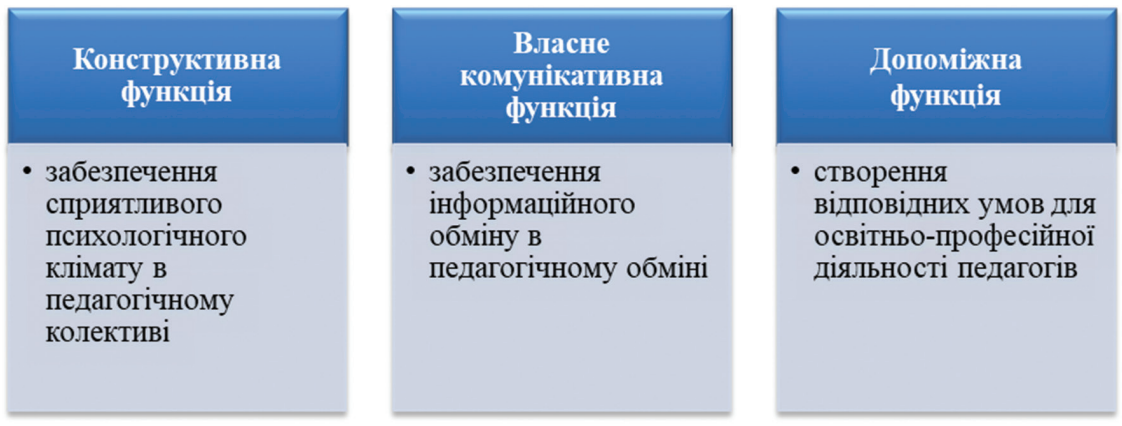

Рис. 2. Функиії педагогічної взаємодї̈ у закладі освіти

Так, конструктивна функція полягає в активному впливі на особистість у спільній діяльності, що забезпечує сприятливий психологічний клімат у педагогічному колективі; допоміжна - у створенні відповідних умов; власне комунікативна - у забезпеченні педагогічних працівників необхідною професійно-важливою інформацією, знаннями та інноваційними тенденціями в освіті.

На нашу думку, плануючи взаємодію з іншими педагогами в контексті реалізації вказаних функцій, педагог як консультант із питань освіти повинен обміркувати не лише зміст спілкування, а й особливості свого мовлення та комунікативної поведінки, що передбачає використання низки вербальних і невербальних засобів спілкування.

Оскільки місія фахівців полягає у «створенні ефективних професійних взаємовідносин, забезпечення освітніх та культурно-освітніх потреб суб'єктів професійної взаємодії, розробці стратегічних цілей та оперативному плануванні й корегуванні освітнього процесу» (Данилова, 1997, с. 47), суспільні трансформації спонукають фахівців щодо створення умов для особистісного розвитку через становлення навичок рефлексивного мислення й здатності бути фасилітатором (за термінологією К. Роджерса).

Із метою вивчення особливостей комунікативної взаємодії в середовищі молодих педагогів на базі університету імені М. П. Драгоманова, Наукового університету оборони імені І. Черняховського нами було проведено дослідження зі студентами (134 особи).

Комунікативні та організаторські здібності педагогів вивчалися за допомогою методики «КОС-2» у педагогічній студії «Антиконфлікт». Аналіз результатів дослідження комунікативних схильностей спеціалістів виявив високий рівень прояву означених комунікативних здібностей. Так, багато педагогів (25\%) продемонстрували дуже високий рівень комунікативних схильностей, $25 \%$ - високий, $12,5 \%$ - середній, $12,5 \%$ - нижче середнього, 12,5\% - низький.

Загальний рівень розвитку емпатії респондентів вимірювався за допомогою методики «Експресдіагностика емпатії», розробленої І. Юсуповим. Дослідження емпатії членів експерименту показали, що половина педагогів (50\%) мають високий рівень розвитку емпатії, що свідчить про здатність до співчуття та розуміння емоційного стану іншого. У спілкуванні вони уважні, намагаються зрозуміти більше, ніж сказано словами. Дуже високий рівень емпатії продемонстрували $12,5 \%$ осіб, середній - 25\%, нижче середнього - $12,5 \%$, низький - $0 \%$ педагогів.

Загальний рівень агресивності і конфліктності освітян вимірювався за допомогою опитувальника А. Басса - А. Дарки. Обчислення «індексу агресивності» виявило, що для 12,5\% опитаних вихователів характерним $€$ високий показник агресивності. Середній рівень продемонстрували 75\% освітян, що вказує на можливість проявів агресії в значущих ситуаціях i, найвірогідніше, в близькому оточенні. $12,5 \%$ респондентів продемонстрували низький рівень агресивності, який свідчить про надмірну замкнутість. На основі отриманих даних, «індекс ворожості» у більшості опитаних знаходиться на низькому та середньому рівнях.

На основі аналізу результатів дослідження комунікативних схильностей, емпатії та рівня агресивності було визначено стилі комунікативної взаємодії респондентів - авторитарний, демократичний та ліберальний. Водночас $38 \%$ осіб продемонстрували демократичний стиль комунікативної взаємодії, 51\% педагогів - ліберальний, $11 \%$ фахівців - авторитарний стиль комунікативної взаємодії.

Як бачимо, молоді педагоги схильні до прояву конфліктності, авторитарності та агресивності, що ускладнює ефективну комунікативну взаємодію у закладі освіти. В основі цього процесу постає науково-методична, дослідницька, проєктна й творча робота освітянина. За цієї умови місія педагога-дорадника у закладі освіти полягає у створенні ефективних професійних взаємовідносин, забезпечення освітніх та культурно-освітніх потреб суб'єктів професійної взаємодії, розробці стратегічних цілей та оперативному плануванні та корегуванні освітнього процесу (Орбан-Лембрик, 2010, с. 372).

В умовах удосконалення комунікативної взаємодії в колективі, на нашу думку, доцільно розширити функції та напрями діяльності педагога-дорадника, охопивши технологічну, педагогічну, дослідницьку, 
експертну, управлінську складові. Вважаємо, що організація освітньої взаємодії може бути багатоплановою, а педагог-дорадник повинен виступати у різноманітних професійних ролях (або одній із них) (див. рис. 3):

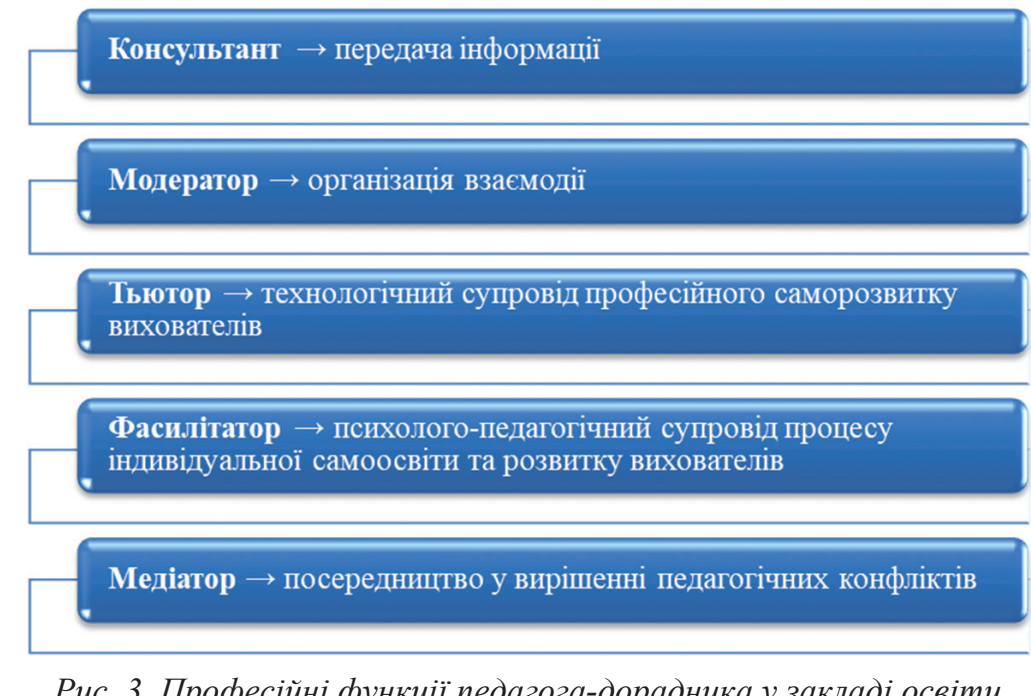

Рис. 3. Професійні функиії педагога-дорадника у закладі освіти

Необхідність визначення шляхів формування комунікативної взаємодії між членами педагогічного колективу дало нам змогу визначити й застосувати таку ефективну форму роботи, як діяльність педагогічної студії «Антиконфлікт». Для удосконалення комунікативної взаємодії у педагогічному колективі закладу освіти та оволодіння необхідними знаннями й уміннями, активізації навчально-пізнавальної діяльності в рамках роботи педагогічної студії виявилося доцільним використовувати активні та інтерактивні методи навчання (проблемні, дискусійні лекції, евристичні бесіди, дискусії, «мозкові штурми», ділові та рольові ігри, моделювання педагогічних ситуацій, імітаційні тренінги, вирішення професійно-орієнтованих педагогічних задач, інтерактивний театр та ін.) (див. табл. 1). Специфіка діяльності методиста-дорадника у закладі освіти в контексті роботи педагогічної студії «Антиконфлікт» обумовила забезпечення ним специфічних педагогічних умов, які сприятимуть формуванню комунікативної культури суб'єктів професійної взаємодії. Зокрема запорукою продуктивної комунікативної взаємодії в педагогічному колективі закладу освіти є спрямованість педагога на спілкування, а також захопленість своєю справою, професійне володіння організаторською технікою, делікатність у стосунках із колегами (Бондарук, 2008, с. 305). Важливою складовою ефективності комунікативної взаємодії в педагогічному колективі закладу дошкільної освіти $\epsilon$ й те, який стиль спілкування притаманний кожному конкретному педагогу (Бутенко, 2009, с. 94), які в нього установки на взаємодію з колегами (Куліш, 2006, с. 17), як він відчуває психологічні особливості та ситуації комунікативної взаємодії (Синдром «професійного вигорання» та професійна кар'єра працівників освітніх організацій, 2004, с. 67). Наші спостереження показують, що в освітян, стиль спілкування яких із колегами будується на основі дружнього ставлення, комунікативна поведінка завжди спрямована на встановлення особистісного контакту, створення ситуації «ми»в контексті спільних роздумів і переживань.

Таблиияя 1

\section{Методи формування комунікативної взаємодії в педагогічному колективі закладу освіти}

\begin{tabular}{|c|c|}
\hline Метод & Характеристика методу \\
\hline \multicolumn{2}{|r|}{ I. Активні методи } \\
\hline $\begin{array}{l}\text { Аналізу } \\
\text { конкретних ситуацій } \\
\text { (case-study) }\end{array}$ & $\begin{array}{l}\text { основними вимогами до методу є: наявність моделі практичної ситуації; колективність, } \\
\text { альтернативність при виробленні рішень; малогрупове та індивідуальне вироблення рі- } \\
\text { шень; наявність системи групового оцінювання діяльності педагогів; наявність керованої } \\
\text { емоційної напруги; різні способи аналізу рішень }\end{array}$ \\
\hline Евристична бесіда & $\begin{array}{l}\text { проводиться у формі спілкування педагога-дорадника з вихователями, з метою обговорен- } \\
\text { ня дискусійних питань взаємодії. Стимулює засвоєння та розуміння теоретичних знань, } \\
\text { вироблення вмінь слухати, оцінювати й приймати думки інших, зрозуміло й аргументовано } \\
\text { висловлювати свою позицію }\end{array}$ \\
\hline $\begin{array}{l}\text { Моделювання педа- } \\
\text { гогічних ситуацій }\end{array}$ & $\begin{array}{l}\text { передбачає створення уявних обставин, які імітують типові реальні проблеми в конфліктній } \\
\text { взаємодії дітей і батьків, що виникають у практиці роботи вихователів. При їх програванні } \\
\text { вихователі вчаться моделювати різні варіанти міжособистісної взаємодії педагога з дітьми } \\
\text { та батьками, оцінювати та обирати оптимальні рішення }\end{array}$ \\
\hline
\end{tabular}


Продовження таблиці 1

\begin{tabular}{|c|c|}
\hline Рольова гра & $\begin{array}{l}\text { полягає в імпровізаційному розігруванні учасниками заданої конфліктної ситуації, у ході } \\
\text { якої вони програють різні ролі, що дозволяє вихователям практично відпрацювати та закрі- } \\
\text { пити нові більш ефективні форми й моделі поведінки в ситуації комунікативної взаємодії. } \\
\text { Застосування рольових ігор сприяє виробленню у вихователів здатності узгоджувати свій } \\
\text { стиль поведінки в конфлікті із професійними вимогами та нормами педагогічної етики }\end{array}$ \\
\hline Імітаційна гра & $\begin{array}{l}\text { програвання простих, відомих дій, які відтворюють, імітують окремі елементи поведінки } \\
\text { учасників конфлікту. Вчить адекватно використовувати засоби вербального й невербаль- } \\
\text { ного спілкування, сприяє формуванню здатності до емоційної стійкості й толерантності у } \\
\text { взаєовідносинах із колегами, дітьми та батьками. Результатом є готовність до швидких } \\
\text { реакцій і прийняття рішень }\end{array}$ \\
\hline \multicolumn{2}{|r|}{ ІІ. Інтерактивні методи } \\
\hline Групова дискусія & $\begin{array}{l}\text { передбачає широке публічне обговорення теоретичного чи практичного питання, що перед- } \\
\text { бачає критичну чи позитивну оцінку інших думок та аргументований захист своєї думки. } \\
\text { Дискусія активізує глибинні асоціації, змушує членів педагогічного колективу вербалізувати } \\
\text { свої комунікативні підходи }\end{array}$ \\
\hline Ділова гра & $\begin{array}{l}\text { передбачає спільний пошук рішень в умовній ситуації побудови певних рішень, використо- } \\
\text { вується для налагодження взаємодії у педагогічному колективі. Проводиться за правилами, } \\
\text { сценарієм, з розподілом і зміною ролей, критеріями оцінки поведінки учасників. Ї̈̈ засто- } \\
\text { сування дозволяє розвинути готовність педагогів до взаємодії }\end{array}$ \\
\hline «Мозковий штурм» & $\begin{array}{l}\text { розвиває творчі здібності, уяву, впевненість, комунікативні вміння вихователів. Спонукає } \\
\text { їх проявляти уяву та творчість, вільно висловлювати нестандартні варіанти пошуку рішень. } \\
\text { Проводиться за етапами: підготовчий, генерування ідей, їх аналіз та оцінка. Важливим є: } \\
\text { відсутність критики; творча атмосфера; свобода асоціацій; заохочення до пропозицій; рівні } \\
\text { права у всіх; фіксація всіх ідей та вибір найкращих, які можна використати }\end{array}$ \\
\hline Метод синектики & $\begin{array}{l}\text { заснований на застосуванні несвідомих механізмів стимуляції творчої активності та при- } \\
\text { йомів створення настрою. Застосовується для пошуку нових ідей за допомогою аналогій і } \\
\text { перенесення завдань на готові рішення, що вже існують в інших сферах діяльності }\end{array}$ \\
\hline «Займи позицію» & $\begin{array}{l}\text { спонукає до виявлення різних позицій педагогів щодо суперечливого питання. Ефектив- } \\
\text { ний з позиції толерантного прийняття різних поглядів на проблему та надання можливості } \\
\text { вихователям оцінити і прийняти протилежні варіанти ії вирішення. Вчить педагога слухати } \\
\text { свого співрозмовника й наводити аргументи }\end{array}$ \\
\hline Ток-шоу & $\begin{array}{l}\text { спонукає до структурованої дискусії, дає змогу контролювати перебіг дискусії, оцінюва- } \\
\text { ти участь кожного вихователя. Проводиться з метою удосконалення у вихователів умінь } \\
\text { публічного виступу, висловлення й захисту особистої позиції, прояву ініціативності у } \\
\text { спілкуванні }\end{array}$ \\
\hline «Коло ідей» & $\begin{array}{l}\text { передбачає вирішення суперечливих питань, створення низки ідей та залучення всіх вихо- } \\
\text { вателів до обговорення професійно значущої проблеми. Усі мікрогрупи виконують одне } \\
\text { завдання, що складається з кількох питань. Відповіді на ці питання мікрогрупи шукають і } \\
\text { презентують по черзі }\end{array}$ \\
\hline $\begin{array}{l}\text { Тренінг (активне } \\
\text { соціально-психоло- } \\
\text { гічне навчання) }\end{array}$ & $\begin{array}{l}\text { дає змогу моделювати різні інтерактивні форми навчання та розширювати передовий } \\
\text { педагогічний досвід, спрямовується на формування навичок комунікативної взаємодії та } \\
\text { позитивного налаштування на контакт з іншими партнерами по спілкуванню }\end{array}$ \\
\hline
\end{tabular}

Оскільки успіх педагогічної діяльності насамперед залежить від ефективної комунікативної взаємодії, то ефективну комунікативну взаємодію доцільно моделювати не «від себе», а від колег, від їх потреб та інтересів у певній групі. Під час ефективної комунікативної взаємодії доцільно використовувати різні види спілкування вербальної і невербальної комунікації, що грунтується на суб'єкт-суб' єктних відносинах та передбачає організацію спілкування «горизонталі». Ефективна комунікативна взаємодія передбачає постійне врахування психологічного стану як окремих колег, так і колективу закладу в цілому, що потребує постійного самоаналізу і рефлексії. Комунікативна співпраця передбачає подолання власних негативних установок стосовно кожного окремого педагога.

Ефективна комунікативна взаємодія грунтується на позитивному настрої і світосприйнятті, що породжує позитивні емоції та спонукає до продуктивного спілкування, вимагає постійного удосконалення інструмента спілкування - власного ділового мовлення.

Висновки. Отже, комунікативна взаємодія є інтегративним, динамічним, структурно-рівневим утворенням, що представлене сукупністю комунікативних знань, умінь і навичок, комунікативно-значущих якостей особистості, котрі забезпечують у своїй взаємодії продуктивну професійну комунікативну діяльність. 
Удосконалення комунікативної взаємодії в колективі закладу регулюється за активної допомоги фахівця дорадчо-методичної сфери. За цієї умови члени колективу повинні бути активно включені у процес професійно-комунікативної взаємодії з різними категоріями осіб: адміністрацією, вихователями, батьками, колегами. Це передбачає необхідність виконання педагогом-дорадником у закладі освіти різноманітних професійних функцій і вимагає цілеспрямованої організації ефективної комунікативної взаємодії спеціалістів у колективі на засадах європейських цінностей та взаєморозуміння.

Перспективи подальших досліджень передбачають подальше вивчення передових зарубіжних методик та технологій педагогічного спілкування, інтерактивних форм вирішення творчих задач та обмін досвідом із метою практичної реалізації у роботі педагогічного колективу.

\section{СПИСОК ВИКОРИСТАНОЇ ЛІТЕРАТУРИ}

Вольнова, Л. (2011). Соціальна психологія: формування компетентності майбутнього фахівця: навч. посіб. Київ: НПУ ім. М. П. Драгоманова. 283 с.

Основи соціальної психології. (2008): навч. посіб. / за ред. М. Слюсаревського. Київ: Міленіум. 496 с.

Куликов, Г. (2012). Шляхи розвитку комунікативної особистості. Менеджмент персоналу. №29. С. 4-6.

Бичок, А. (2010). Формування культури професійного спілкування майбутніх вихователів: автореф. дис. ... канд. пед. наук: 13.00.04. Тернопіль. 23 с.

Педагогічна творчість, майстерність, професіоналізм у системі підготовки освітянських кадрів: здобутки, пошуки, перспективи: монографія. (2015) / керівн. авт. кол. Н. В. Гузій. Київ: НПУ ім. М. Драгоманова. 432 с.

Гаврилюк, О. (2007). Формування комунікативної культури майбутніх учителів засобами позааудиторної роботи: автореф. дис. ... канд. пед. наук: 13.00.04. Кіровоград. 22 с.

Коновчук, Н. (2012). Основні причини та профілактика професійного вигорання вихователів. Правничий вісник Університету «КРОК». Київ. Вип. 14. С. 91-95.

Руденко, Л. (2015). Формування комунікативної культури майбутніх фахівців у навчальних закладах: монографія. Львів: Піраміда. 342 с.

Максименко, С. (2005). Технологія спілкування (комунікативна компетентність учителя: сутність і шляхи формування). Київ: Главник. 112 с.

Яновська, О. (2017). Ділове спілкування як чинник результативності діяльності педагогічного колективу: дис... канд. психол. наук. Київ. 226 с.

Данилова, Г. (1997). Методичні служби України: проблеми управління, професійна підготовка: навч.-метод. посіб. Київ: ІЗМН. 224 с.

Орбан-Лембрик, Л. (2010). Психологія професійної комунікації: навч. посіб. Чернівці: Книги - XXI. $528 \mathrm{c}$.

Бондарчук, О. (2008). Соціально-психологічні основи особистісного розвитку вихователів у професійній діяльності: монографія. Київ: Науковий світ. 318 с.

Бутенко, Т. (2009). Обгрунтування педагогічної технології формування комунікативної компетентності вихователів. Педагогіка формування творчої особистості у вищій $i$ загальноосвітній школах: зб. наук. праць Класичного приватного університету. №3. С. $94-98$.

Куліш, О. (2006). Формування основ професійного спілкування у майбутніх вихователів: автореф. дис... канд. пед. наук: 13.00.04. Луганськ. 20 с.

Синдром «професійного вигорання» та професійна кар'єра працівників освітніх організацій: навч. посіб. (2004) / за ред. С. Максименка, Л. Карамушки, Т. Зайчикової. Київ: Міленіум. 264 с.

\section{REFERENCES}

Volnova, L. (2011). Sotsialna psykholohiia: formuvannia kompetentnosti maibutnoho fakhivtsia [Social psychology: the formation of competencies of the future specialist]: navch. posib. Kyiv: NPU im. M. P. Drahomanova. 283 s. [in Ukrainian].

Osnovy sotsialnoi psykholohii [Fundamentals of social psychology]: navch. posib. (2008). Kyiv: Milenium. 496 s. [in Ukrainian].

Kulykov, H. (2012). Shliakhy rozvytku komunikatyvnoi osobystosti [Ways of development of communicative personality]. Menedzhment personalu. № 29. C. 4-6. [in Ukrainian].

Bychok, A. (2010). Formuvannia kultury profesiinoho spilkuvannia maibutnikh vykhovateliv [Formation of a culture of professional communication of future educators]: avtoref. dys. ... kand. ped. nauk: 13.00.04. Ternopil. $23 \mathrm{~s}$. [in Ukrainian].

Pedahohichna tvorchist, maisternist, profesionalizm u systemi pidhotovky osvitianskykh kadriv: zdobutky, poshuky, perspektyvy [Pedagogical creativity, skill, professionalism in the system of educational training: achievements, searches, prospects]: monohrafiia. (2015). NPU im. M. Drahomanova. 432 s. [in Ukrainian].

Havryliuk, O. (2007). Formuvannia komunikatyvnoi kultury maibutnikh uchyteliv zasobamy pozaaudytornoi roboty [Formation of a communicative culture of future teachers by resources of extracurricular work]: avtoref. dys. ...kand. ped. nauk: 13.00.04. Kirovohrad. 22 s. [in Ukrainian].

Konovchuk, N. (2012). Osnovni prychyny ta profilaktyka profesiinoho vyhorannia vykhovateliv [The main causes and prevention of professional burnout of teachers]. Pravnychyi visnyk Universytetu «KROK». Kyiv. Vyp. 14. S. 91-95. [in Ukrainian].

Rudenko, L. (2015). Formuvannia komunikatyvnoi kultury maibutnikh fakhivtsiv u navchalnykh zakladakh [Formation of communicative culture of future specialists in educational institutions]: monohrafiia. Lviv: Piramida. 342 s. [in Ukrainian].

Maksymenko, S. (2005). Tekhnolohiia spilkuvannia (komunikatyvna kompetentnist uchytelia : sutnist i shliakhy formuvannia) [Communical technology (teacher's communicative compertence: essence and ways of formation)]. Kyiv: Hlavnyk. 112 s. [in Ukrainian].

Yanovska, O. (2017). Dilove spilkuvannia yak chynnyk rezultatyvnosti diialnosti pedahohichnoho kolektyvu [Business communication as a factor in the effectiveness of the teaching staff]: dys... kand. psykhol. nauk. Kyiv. 226 s. [in Ukrainian]. 
Danylova, H. (1997). Metodychni sluzhby Ukrainy: problemy upravlinnia, profesiina pidhotovka [Methodical services of Ukraine: management problems, professional training]: navch.-metod. posib. Kyiv: IZMN. 224 s. [in Ukrainian].

Orban-Lembryk, L. (2010). Psykholohiia profesiinoi komunikatsii [Psychology of professional communication]: navch. posib. Chernivtsi: Knyhy - XXI. 528 s. [in Ukrainian].

Bondarchuk, O. (2008). Sotsialno-psykholohichni osnovy osobystisnoho rozvytku vykhovateliv u profesiinii diialnosti [Socio-psychological foundations of personal development of educators in professional activities]: monohrafiia. Kyiv: Naukovyi svit. 318 s. [in Ukrainian].

Butenko, T. (2009). Obgruntuvannia pedahohichnoi tekhnolohii formuvannia komunikatyvnoi kompetentnosti vykhovateliv [Substantiation of the pedagogical technolo- gy of the formation of the communicative competence of educators]. Pedahohika formuvannia tvorchoi osobystosti u vyshchii i zahalnoosvitnii shkolakh: zb. nauk. prats Klasychnoho pryvatnoho universytetu. № 3. S. 94-98. [in Ukrainian].

Kulish, O. (2006). Formuvannia osnov profesiinoho spilkuvannia u maibutnikh vykhovateliv [Formation of the foundations of professional communication among future educators]: avtoref. dys... kand. ped. nauk: 13.00.04. Luhansk. 20 s. [in Ukrainian].

Syndrom «profesiinoho vyhorannia» ta profesiina kariera pratsivnykiv osvitnikh orhanizatsii [The syndrome of «professional burnout» and the professional career of employees of educational organizations]: navch. posib. (2004). Kyiv: Milenium. 264 s. [in Ukrainian].

Дата надходження до редакиії: 25.08.2021 p.
УДК 371.2

DOI: 10.37026/2520-6427-2021-108-4-62-68

\section{Тетяна КОВБАСЮК,}

кандидат педагогічних наук, завідувач кафедри педагогіки, психологї та корекційної освіти Рівненського обласного інституту післядипломної педагогічної освіти, м. Рівне, Украӥна ORCID: 0000-0003-4551-3494 e-mail:kovbasyuktl@ukr.net

\section{ПСИХОЛОГО-ПЕДАГОГІЧНІ ОСОБЛИВОСТІ МОТИВАЦЇ̈ ПЕДАГОГІВ ДО ПРОФЕСІЙНОЇ ДІЯЛЬНОСТІ}

\begin{abstract}
Анотація. У статті здійснено аналіз психолого-педагогічних особливостей мотиваиії педагогів до професійної діяльності, досліджено ієрархічну структуру мотиваційної сфери, визначено основні мотиви діяльності вчителя. Проаналізовано фактори, шо впливають на формування професійної мотивації, визначено умови успішної професійної самореалізації. Для проведення емпіричного дослідження використано такі методики: тест «Мотивація професійноі діяльності» (методика К. Замфір у модифікаиії A. Peана), тест «Діагностика рівня професійної спрямованості» (Т. Дубовииької), методика «Задоволеність педагога обраною професією» (у модифікачиї А. Реана). Виявлено, що в респондентів, які нешодавно розпочали свою професійну діяльність, домінують мотиви досягнення сочіального престижу і поваги оточуючих та задоволення від самого процесу і результатів праиі. Встановлено, щзо в учителів, стаж педагогічноі діяльності яких складає 6-15 років, найбільш актуалізованими є мотиви кар'єрного зростання та матеріального заохочення. Виявлено, щяо в осіб зі значним
\end{abstract}

стажем педагогічної діяльності домінують такі мотиви, як-от: можливість більше самореалізуватися саме в иій діяльності, грошова винагорода, бажання кар'єрного зростання, задоволення від самого процесу і результатів праці. Досліджено рівень професійної спрямованості педагогів, доведено, щзо з досвідом він поступово зростає від пасивного до креативного, однак в учителів, які працюють за спеціальністю більше 16 років, рівень креативності дещь знижується. Виявлено, щьо більшості педагогів притаманний середній рівень задоволеності професійною діяльністю, однак спостерігається ї̈ зростання відповідно до стажу роботи. Визначено, що формування та збереження позитивної внутрішньої мотивачї до професійної діяльності є одним із факторів, що сприяють підвищенню ефективності педагогічної взаємодії та створюють сприятливі умови для самореалізачії вчителя у професійній діяльності.

Ключові слова: мотив, мотивація, мотиваиіиина сфера, педагогічна діяльність, професійна самореалізаиія. 